“íş, Güç” Endüstri İlişkileri ve İnsan Kaynakları Dergisi

Cilt:10 Sayı:1, Ocak 2008, ISSN: 1303-2860

“iş, Güç” The Journal of Industrial Relations and Human Resources

Vol:10 No:1 January 2008, ISSN: 1303-2860

\title{
MAJOR PHILOSOPHIES OF STRATEGIC HUMAN RESOURCES MANAGEMENT AND THEIR EFFECTS ON THE JOB SATISFACTION, AFFECTIVE COMMITMENT TO ORGANIZATION AND COMPETITIVE ADVANTAGE
}

\author{
BELIZ DERELİ \\ Yrd.Doç.Dr.İstanbul Ticaret Üniversitesi, Ticari Bilimler Fakültesi
}

\begin{abstract}
Globalization, international competition and strong technological changes entailed some important revisions on the organizations' structures and their functions. By these changes, the companies began to take their decisions, develop their plans according to the strategies. Strategic Human Resources Management (SHRM) intends to assist in formulation of the firm's strategic direction and needs. Also it's a critical part of any organization's drive toward a competitive advantage. Business strategies and Human Resources Management processes should be thought together for the competitive advantage. SHRM accomplishes the firm's strategic needs such as survival, growth, adaptability and profitability. SHRM has many components including policies, culture, values, practices and philosophies. These components help to firm for adapting to environmental changes, developing human capital, changing organizational culture, adopting the employees for change and supporting business strategies. This study aims to explore the major philosophies within the context of strategic human resources management and their effects on the company management outcomes such as job satisfaction, affective commitment to organization and competitive advantage.
\end{abstract}

Keywords: Strategic Human Resources Management, Learning Organizations, Outplacement, Quality of Work Life, Job Satisfaction. 


\section{ÖZET}

Küreselleşme, uluslararası rekabet ve güçlü teknolojik değişimler organizasyonların yapılarında ve fonksiyonlarında bazı önemli yenileme çalışmalarını gerekli kılmıştır. Bu değişimlerle birlikte şirketler, stratejiler doğrultusunda kararlar almaya ve planlar geliştirmeye başlamışlardır. Stratejik Insan Kaynakları Yönetimi(SiKY) şirketin stratejik yönünün ve ihtiyaçlarının belirlenmesine yardımcı olmayı amaçlamakla birlikte işletmenin rekabet avantajı yakalamasında önemli bir usurdur. Rekabet avantajı için iş stratejileri ve Insan Kaynakları yönetimi süreçleri birlikte düşünülmelidir. SKIY, şirketin hayatta kalma, gelişim, uyum sağlayabilme ve karlılık gibi çeşitli stratejik intiyaçlarını gerçekleştirmekte ve şirket politikası, kültürü, değerleri, uygulamaları ve felsefeleri gibi çeşitli bileşenleri içermektedir. Bu bileşenler firmaya, çevresel değişimlere uyum sağlamak, iş gücünü geliştirmek, işletme kültürünü değiştirmek, çalışanları değişimlere uyumlarını sağlamak ve iş stratejilerini desteklemek konularında yardımcı olmaktadır. Bu çalışma, stratejik insan kaynakları yönetiminde yeralan temel felsefeleri ve bunların iş tatmini, işletmeye bağlılık ve rekabet avantajı üzerindeki etkilerini incelemeyi amaçlamaktadır.

Anahtar Kelimeler: Stratejik Insan Kaynakları Yönetimi, Öğrenen Organizasyonlar, İşten Çıkarılanlara Destek Hizmeti (Outplacement), Çalışma Hayatının Kalitesi, İş Tatmini.

\section{INTRODUCTION}

Recently, human resources management literature is using the term "strategic" to support the Strategic Management by integrating the Human Resources Management functions with the firm's strategies. A strategic approach to human resource management includes a set of Human Resources policies, practices that develop the firm's human capital (employees' knowledge, skills and abilities) and contributes the achievement of the business objectives (Huselid, Jackson and Schuler, 1997:38).

In Strategic Human Resources Management (SHRM), there are some philosophies which are a statement of the organization's vision about the human resources and have also very important role to sustain the competitive advantage, create the organizational commitment, job satisfaction and improve the employees' motivation.

This paper consists of three main parts. In the first part, the strategy and it's relation with Human Resources Management has been explained. In 
the second part, the theoretical knowledge about the major philosophies such as learning organization, quality of work life, outplacement within the context of SHRM have been presented. In the third part, the effect of these philosophies on the job satisfaction and competitive advantage was investigated within the firms who work in different sectors and employ these philosophies.

\section{STRATEGY AND HUMAN RESOURCES MANAGEMENT}

A strategy is a unified, comprehensive and integrated long term plan for achieving the organizations' objectives (Jauch and Glueck, 1988:57). Strategic management is the process of developing policies and plans to achieve these objectives, and allocating resources so as to implement the plans. It is the highest level of managerial activity which involves matching the companies' strategic advantages to the business environment the organization faces (http://en.wikipedia.org/wiki/Strategic management). Increasingly, human resources management literature is using the term "strategic" to support the Strategic Management by integrating the Human Resources Management functions with the firm's strategies. A strategic approach to human resource management includes a set of Human Resources policies and practices that develop the firm's human capital (employees' knowledge, skills and abilities) contributes the achievement of the business objectives (Huselid, Jackson and Schuler, 1997:38).

Strategic management of human resources is a multidimensional process with multiple effects. These effects can include any parties that have interests (or a stake) in the success, or performance of a firm. All these parties which can be defined as stakeholders stand to benefit from a firm's successful operation, including owners, suppliers, customers, employees, local communities, governments, trade association, owners/stockholders and society (Miller, 1998:113).

In SHRM, the human resources management practices which include compensation, training, search and selection, staffing, systems of work place governance, job design and work organization are most effective because they are matched with strategic goals of organizations. Strategic HRM also evaluate the effectiveness of these practices which help the organization meet its goals (Hunter, 1995). Sometimes SHRM is viewed as the exclusive responsibility of Human Resources Managers and their team. SHRM is not a task, limited to elite 
"Strategists" or a group of "Strategic Planners", but rather, it's a set of managerial skills that should be used throughout the organization, in a wide variety of functions (Miller,1998:118). Besides top executives, also general managers, medium level managers and supervisors throughout the entire organizations are coming to have new responsibilities and more important roles to play in strategic human resources management.

Strategic Human Resources Management is a very important part of any organization's drive toward a competitive advantage and to win this advantage. HR professionals have to learn using macro-focused techniques such as environmental analysis and environmental scanning, organizational analysis and design, internal human resources analysis, human resources planning and they have to learn integrating the information which comes from these techniques with the organization's strategic business plan (Tokesky and Kornides, 1994:62).

So many factors are effective in the combination process of the human resources management and the organization's strategic management (Jauch and Glueck,1988:70).

Density in Competition: This external challenge affects an organization's demand for human resources. The competitor analysis which includes the human resources strengths and weaknesses of competitors is very important to handle this challenge.

Technology: Technological changes are difficult to predict. Some applications like mechanization and automation cause mass unemployment and make some jobs monotonous, repetitive and tedious. Against these problems, corporations began to develop new programs for creating job satisfaction and improving the productivity. They provide additional training opportunities to the employees. In this way the employees could adopt to technological innovations easily (Werther and Davis, 1989:89).

Environmental Changes: This category includes actions taken by the human resources management department in response to external events or trends, such as budget cuts, tight labour markets, inflation, changing demographic characteristics of workers, unemployment, social, political and legal challenges, etc. To reduce the negative effects of these changes, human resources management style should be based on a philosophy of generating numerous alternatives and 
initiatives and should be proactive rather than reactive, sensitive rather than stoic.

Organizational strategic decisions and ventures: Strategic decisions are determined by environmental problems and opportunities and internal strengths and weaknesses (Jauch and Glueck,1988:71). The organization's strategic decision sometimes commits the firm to longrange factors - such as growth rates and new products, markets, or services. By these factors, firms could determine easily the number and types of employees needed in the future (Werther and Davis, 1989:92). Strategic Human Resources Management is also analysis of the gap between current and required capacity for each ventures. If the firm has decided to enter new business, reorganization after a merge or an acquisition, serve a new client, expand services into new areas, human resources department plays a strategic role by recruiting new employees with the requisite skills or improving the existing employees' essential knowledge, skills and abilities, developing the capacities through training and development activities so that the company can respond to any opportunity or threat (Tompkins, 2002:45).

\section{MAJOR PHILOSOPHIES IN STRATEGIC HUMAN RESOURCES MANAGEMENT}

These philosophies are a statement of the organization's vision about the human resources and they present the kind of culture and work climate that must be established and the specific attitudes and behaviours that must be elicited if the company is to achieve its vision of success. Also these philosophies include much positive effectiveness such as supporting the competitive advantage to the companies, improving the employees' job satisfaction and loyalty.

\subsection{Quality of Work Life}

The introduction of new technologies, products and processes brought new risks and health problems (Biggins, 1991:61). Besides technological changes, there were also big changes in environment, organizations' structure and their management style, capital investment and work force all influence the organization's productivity (Werther and Davis, 1989:109). While the nature of the labor force was changing, the need for higher educated and skilled workers increased. The employees were more aware, educated and were demanding more say in their 
jobs. On the other hand, the growing specialization and professionalism of jobs, rising cost of wages and benefits, the shift to labor intensive services all combined to raise the labor effects in the productivity (Rosow,1977:72). To gain the advantage of these changes, human resources management departments are most involved with efforts to improve productivity through changes in employee relations and provide a good quality of work life to the employees.

Quality of Work Life means to have good management style, good working conditions, good pay and benefits system, good employeeemployer relations, good aims such as improving the experience of the employees with jobs and their contributions to the organization' effectiveness (Werther and Davis, 1989:110). Humanization of work place, work restructuring, work place democracy are very similar expressions to quality of working life (Cherns, 1975:22).

Ever since the concept of Quality of Work Life (QWL) was first used over 30 years ago, a range of definitions and theoretical constructs have succeeded each other with the aim of mitigating the many problems facing the concept. Carlson (1980) defines QWL as an organizational goal, which the business is perpetually striving to achieve. Moreover, still from the organizational point of view, this author considers QWL as a philosophy which, even though it varies with organizations, brings them together under a common denominator: human dignity. According to Kerce and Boot-Kewley (1993) QWL is a way of thinking about people, work and organization. Sirgy et al.(2001) recently published a validation of a QWL questionnaire based on a definition - that returns to the concept of job satisfaction. They defined OWL as a philosophy which provides the employee satisfaction with a variety of needs through resources, activities, and outcomes stemming from participation in the workplace (Martel and Dupuis, 2006). Finally, in the study of Huang and friends, QWL is defined as favorable conditions and environments of work and life aspects such as family/work life balance, self-actualization, compensation, and supervisory behavior (Huang, Lawler and Lei, 2007:735).

This philosophy includes some conceptual categories such as adequacy in compensation, safe and healthy working conditions, employee benefit programs, job security, free collective bargainning, opportunity for continued growth and security, social integration 
in the work organization, constitutionalism in the work organization, work and total life space, social relevance of work life (Lippitt, 1978; Rosow,1977 ).

These criteria can be associated with four key factors (Lippitt, 1978:6):

-The work itself which generates higher levels of accountability and responsibility because it is characterized by systems which encourage direct feedback on performance, clear work goals fewer controls with more accountability and appropriate involvement in decision-making.

-The individual who grows personally and professionally through his or her work roles and relationships, fostered and consistently improved through processes of role clarification; opportunities for individualization, self - identity and learning; linking individual, work and life goals, tangible support from superiors.

-The work output of improved quality resulting from enlarged responsibilities, intergroup collaboration, work completed in units rather than in fragments, rewards for quality and innovation and measurable goal attainment.

- Organizational functions and structures built in an open system and providing a climate for creativity, two-way communication, a system perspective, respect for the individual and ongoing organization development.

So if the companies apply the quality of work life philosophy depending on these criteria and factors which were mentioned above, this philosophy improves the employees' satisfaction and their contributions to their organization's overall achievements and in the long run period supports the company for gaining the competitive advantage.

\subsection{The Learning Organization}

The rapid changes in market environments, technology and the limits of the competition have created the need for flexibility in organization's structure and its performance. People are very important source for gaining the competitive advantage by employing their skills, knowledge and experience that's why the investment in people's learning and development is essential especially for meeting the future work demands of the organization (West, 1994:89). 
To survive in the continuously changing information environment, organizations should be more agile and flexible. Rigid rules, intensive bureaucracy, and straight hierarchical steps prevent the organizations from applying new technologies, gaining the competitive advantage and meeting the expectations of users. Organizations should encourage the learning, experimenting and risk taking. They need to develop strategies which will move the organization forward and create proactive responses to change. To achieve this, they need employees who adopt to change, accept challenges, can develop new skills suitable to the organization's mission, goals, and objectives (Giesecke and McNeil,2004:65).

According to Senge (1990:3) learning organizations are a place where people continually expand their capacity to create the results they truly desire, where new and extensive patterns of thinking are nurtured, where collective aspiration is set free and where people are continually learning to see the whole together. This formulation points to the attributes of organisations and individuals and a special way of behaviour of people in learning organization (LO). The concept of LO with its features is systemised by Senge's model of five components or disciplines (1990): systems thinking, personal mastery, mental models, team learning, and building shared vision (described in more detail in the following section, Table 1). A discipline is understood by Peter Senge as a series of principles and practices integrated into organisation. Many researchers have found several more dimensions describing an LO and complementing Senge's model. According to Moilanen (2001) the holistic view should be added. Silins et al. (2002) define seven dimensions that characterise schools as LOs: environmental scanning, vision and goals, initiative and risk-taking, review, recognition and reinforcement, and continuing professional development (Mets and Torokoff, 2007:141). What follows are twelve top tips suggested by the authors, drawn from a compilation of the workshop presentation, subsequent debate and ongoing reflections on the importance of learning (Stinson; Pearson and Lucas, 2006):

Tip 1: Value and recognize the need for life long learning

Tip 2: Energize active learning amogst employees

Tip 3: Develop self - awareness

Tip 4: Be open new ideas

Tip 5: Make time for learning 
Tip 6: Teams, departments and organizations should provide protected time for learning

Tip 7: Develop a shared team, departmental or organizational vision

Tip 8: Take time out to build the team

Tip 9: Develop leadership skills

Tip 10: Learn from mistakes

Tip 11 : Think about the wider environment

Tip 12 : Take time for socializing after work and allowing selfrefreshment

The learning organization philosophy provides learning and selfdevelopment opportunities to all employees. The customer is a very essential part of the organization rather than as passive recipients of the service or product provided. They are involved in the organization by actively seeking their views and opinions on how the service/product can be improved (Wilkinson, Rushmer and Huw, 2004:154). The learning organization has a vision and transfers this vision effectively to the employees and allows the employees to make mistakes without blame (Hill, 1996:61).

James Collins and Jerry Porras of Stanford University examined eighteen companies that were premier institutions in their industries; they were widely admired and averaged being in business almost one hundred years; they had outperformed the general stock market by a factor of 15 since 1926. The results were published in their book, Built to Last: Successful Habits of Visionary Companies. They discovered several timeless qualities of the exceptional companies (Freed, 2001:17):

- They have core values. The core values form solid foundations that do not change

because of current fads.

- They are driven by more than making money. Although making money is one objective, it is not the primary objective.

- They focus on continuous improvement. The companies focus on continually improving

themselves rather than on beating the competition. 
- They learn from failures. They rely more on trial and error than on systematic strategic

planning.

This philosophy has important core competencies such as the systematic problem solving, doing an experiment and trying the new approaches, learning from past experiences, learning from another, creating and sharing the knowledge, presenting opportunity to apply new skills and knowledge, analysing the needs of education, training and development, applying the effective performance and personal development plans, developing identified and protected education and training budget, sustaining change and improvement, building knowledge management system, empowering the work force (Garcarz and Chambers, 2003:73), increasing the consideration of and respect for individual contributions made while working in a team environment (Jay, 2001:79). When sufficient and appropriate learning takes place throughout the organization all time, people could understand easily the need and direction for change, they also will get clear information about the new values, processes and skills are likely to be needed and where relevant changes and development are happening in the organization (West, 1994:103).

\subsection{Outplacement}

Outplacement is a consulting service for the employees who have been terminated or whose jobs have been eliminated, to face their job loss with renewed self-confidence, to learn effective job search strategies and techniques and to conduct a successful job search campaign (Pickman, 1994:49). This term includes many aspects of the process such as consulting, counselling, coaching, instructing, and helping employers and employees for the employment changes. The outplacement service consults the specific matters of downsizing, reorganization, termination procedures and also assists to laid-off employees (Meyer and Shadle, 1994:110).

Corporate downsizing and restructuring are likely to continue long into the 1990s as businesses attempt to adjust to a new world economic order. Just as companies call on outside consultants to help them manage difficult business transitions, many firms are now doing the same for their employees. This new type of employee assistance is 
called outplacement and it can help laid-off workers regain their equilibrium, plan for hew careers, and become gainfully re-employed. In the past, firms mainly provided outplacement services to upper-level managers. Such assistance is now becoming available to middle management, professional, and technical workers (Kirk, 1994).

The lay off decision depends on three main reasons. The first reason is related with the employees' insufficiency and their negative behaviors, attitudes such as damage to workplace, provoke the other employees against to employer, alcohol or drug addiction, to be in conflict with others frequently. The second reason is related with the environmental changes such as technological developments, greater competition, new industries, political and legal changes, economic crisis, new occupations, and the necessities of the new management approaches. The third reason is the company's strategic decisions which are occurred by the environmental changes and affect the structure of the organization such as downsizing, mergers and acquisitions, reengineering, privatization. The companies provide the outplacement service depending on the last two reasons which appear because of the job and workplace requirements. There are two providers in this service. The one is the corporate outplacement firm which contracts with companies for assisting the employers, the outplaced employees and perhaps, the survivors. The other provider is the organization itself (Meyer and Shadle, 1994:112).

The outplacement service covers a full range of career related programs such as; (Knowdell, Branstead and Moravec, 1994:76)

- counselling the employees on how to deal with the emotional issues related to termination.

- providing career assessment programs to determine the employees' skills level and interests.

- conducting workshops on how to develop job search materials including resume, cover letters and effective letters to use in direct approaches to target companies (Pickman, 1994:58).

- preparing for the interview,

- assisting in formulation of job search techniques including networking and responding to newspaper advertisements.

- coaching and recommending about utilizing executive search and placement agencies, 
In the study which was carried out by Westaby (2004), a sample of 1,880 managers and executives using the services of large outplacement organization was examined. Results demonstrated that displaced managers and executives participating in outplacement that demonstrated higher levels of outplacement support took more time to find reemployment, had greater likelihood of reemployment, and had higher salaries in new jobs than individuals participating in programs with lower levels of outplacement support. So the high levels of outplacement support can provide considerable benefit to displaced employees. Another important result from this study suggests that the displaced employees prefer the outplacement service more than receiving severance pay which is offered by the companies instead of the outplacement service. They seriously consider outplacement as a viable option, especially given the amount of stress that could be associated with pursuing a job search without professional service.

There are several reasons for using outplacement services (Sweet, 1991):

\section{To protect the company's name}

The lay off process does not affect only the employees; it also affects the employer or the public image of the company. If this process is managed unconsciously, this causes to falling of the shares, reducing the numbers of the customers, losing the power in the price bargaining with the suppliers.

In the termination process some laid-off employees might feel angry, so he/she could try to damage the company's production, the working place or brings a high cost lawsuit against the company. Especially the loosing of one lawsuit causes the negative effects on the company's prestige, market share and the motivation and loyalty of the retain employees. If the outplacement service is provided to the employee, it reduces the likelihood of lawsuits.

\section{Social responsibility}

Globalization brought so many important changes to the environment in which companies operate, and in the way they do business. These changes force the companies to investigate management models, structures and the types of corporate culture that bring social and ethical responsibility to the company management. By the corporate social responsibility organizations give an importance to the integration 
of social and environmental concerns such as human rights, environmental protection, and equality of opportunity in their business activities (Jauch and Glueck, 1988:38). Applying the social responsibility programs is effective for creating brand loyalty, improving the employees' quality, strengthening the organization's public image and partnerships with stakeholders (http://www.prsa.org/ Networking/ ssr/index.asp?ident=ec1). Providing the outplacement service is very important indicator of the company's social responsibility.

3. To reduce the negative effect of the lay off on the employees who remain in the organization

Another reason for using outplacement services is to maintain the morale of the employees who keep working in the company. They are also called "survivors" who remain within an organization after a significant cut in the workforce. Although the termination is handled well, sometimes it causes to the employees' negative reactions such as anger, fear and feeling of unfairness. Morale couldn't be provided unless the situation is addressed and handled by management (Meyer and Shadle, 1994:115).

Organizations need to recognize and manage the uncertainties which arise in survivors' minds during the lay off period. Besides this, knowing that outplacement services are being offered to the laid off employees can have a positive affect on the survivors. Although it might not completely calm employees' fears, it provides a confidence to know that if they will to be next, they can expect the same assistance that was offered to their former colleagues (Pickman, 1994:72).

Outplacement services are considered standard for laid-off employees of large organizations and are designed to assist the displaced people in finding the right position within a short period of time and with minimum trauma. Not only are these services important to those laid off, but research of 400 H.R. professionals by Lee Hecht Harrison, an international career services consulting firm, found that there was clear benefit to survivors of layoffs when organizations visibly support their terminated employees ( $88 \%$ of those who did so saw a positive impact). Many of the HR executives interviewed noted that it was critical for survivors to know that those laid off had been provided with severance pay and outplacement services (Smith and Walker, 2000:135) 


\section{RESEARCH}

\subsection{The Aim of the Study}

The study's aim was to find the effects of Strategic Human Resources Management's major philosophies (learning organization, quality of work life and outplacement) on the employees' job satisfaction, affective commitment to organization and the firms' competitive advantage.

\subsection{Methodology}

The data is collected by survey questionnaire method designed with a set of questions that are mainly derived from literature, as well as the directions of the managers working in the firms. The process of data collection continued for two months, from March 2005 through April 2005. The questionnaires were sent to the white collar employees of the selected firms by post or e-mail.

In the beginning of the research, an information has been gathered from various publications, congresses and seminars that 13 big-scaled companies which are operating in the services and manufacturing sector have been implementing the SHRM's major philosophies.

The next process was to interview with the HR Managers of these 13 companies but only 7 of them accepted the interview offer. At the end of the interviews, it has been reached to the conclusion that the philosophies which are under research have been implemented at these 7 companies.

In the process of data collection by questionnaire method, 2 companies out of 7 rejected the questionnaire implementation because of their management principles. So the sampling frame of the study consists of the employees of 5 firms which having more than 100 white collar employees.

In total 200 questionnaires were distributed to the white collar employees of the firms. However the actual sample size (i.e.usable return and completed questionnaires) was 97 with a response rate of 
$49 \%$. There was no eliminated questionnaire due to excessive missing data.

The socio-demographic profile of the respondents showed that half of the respondents were female $(56 \%)$. More than half of the respondents $(65 \%)$ were between the ages of $25-35$ and $72 \%$ of the respondents were at least university graduates. $56 \%$ of the respondents were having non-managerial (no subordinates) positions working in miscellaneous departments and more than half of the respondents $(70 \%)$ were having tenure of more than 3 years.

\subsection{Hypotheses}

In the research, the relationship between these philosophies and company management is investigated in terms of three main indicators which are commonly used in literature: employees' job satisfaction, affective commitment to organization and their perceptions about firms' competitive advantage. To this end, hypothesis mentioned below are developed for the research:

$\mathbf{H}_{1}$ : Major philosophies in SHRM (a) learning organization, (b) quality of work life and (c) outplacement in SHRM have an effect on employees' job satisfaction.

$\mathbf{H}_{2}$ : Major philosophies in SHRM (a) learning organization, (b) quality of work life and (c) outplacement have an effect on affective commitment to organization.

$\mathbf{H}_{3}$ : Major philosophies in SHRM (a) learning organization, (b) quality of work life and (c) outplacement have an effect on firms' competitive advantage.

\subsection{Measures}

The constructs in this study were measured using measurement scales developed by the researcher and adopted from prior studies. All constructs were measured using five-point Likert type scale which anchors strongly agree (5) and strongly disagree (1). 
In the study employees were asked to evaluate their firms in terms of learning organization features. To this end a scale was developed consisting of 8 items (i.e. "In this company, employees reach the information that they need timely") (Table 1). Results of factor analysis (varimax rotated; $\mathrm{KMO}=, 89$ Barlett's Test $\mathrm{p}<0,01$; total variance explained $63 \%$ ) confirmed that the scale consisted of one dimension and Cronbach a value of the scale (.91) showed it was reliable. A higher result from the scale indicates that the employee perceives the firm as a learning organization.

The quality of working life was measured by a scale consisting of 9 items (i.e. "Caring the employees' work-family life balance") asking the employee whether he/she was satisfied with several aspects related to quality of working life presented by the firm (Table 2). Results of factor analysis (varimax rotated; $\mathrm{KMO}=, 80$ Barlett's Test $\mathrm{p}<0,01$; total variance explained $53 \%$ ) confirmed that the scale consisted of one dimension and Cronbach $\alpha$ value of the scale (.83) showed it was reliable.

Since all firms in the sampling frame were employing outplacement, in order to evaluate the effect of outplacement on the dependent variables, participants' satisfaction level of the outplacement applications in their firms were asked with only one question "Are you satisfied with your firm's support to the job leavers in finding a new job?" using five point Likert-scale.

Since all firms in the sampling frame were employing outplacement, in order to evaluate the effect of outplacement on the dependent variables, participants' satisfaction level of the outplacement applications in their firms were asked with only one question "Are you satisfied with your firm's support to the job leavers in finding a new job?" using five point Likert-scale. 
Since all firms in the sampling frame were employing outplacement, in order to evaluate the effect of outplacement on the dependent variables, participants' satisfaction level of the outplacement applications in their firms were asked with only one question "Are you satisfied with your firm's support to the job leavers in finding a new job?" using five point Likert-scale.

Since all firms in the sampling frame were employing outplacement, in order to evaluate the effect of outplacement on the dependent variables, participants' satisfaction level of the outplacement applications in their firms were asked with only one question "Are you satisfied with your firm's support to the job leavers in finding a new job?" using five point Likert-scale.

Since all firms in the sampling frame were employing outplacement, in order to evaluate the effect of outplacement on the dependent variables, participants' satisfaction level of the outplacement applications in their firms were asked with only one question "Are you satisfied with your firm's support to the job leavers in finding a new job?" using five point Likert-scale.

Since all firms in the sampling frame were employing outplacement, in order to evaluate the effect of outplacement on the dependent variables, participants' satisfaction level of the outplacement applications in their 
firms were asked with only one question "Are you satisfied with your firm's support to the job leavers in finding a new job?" using five point Likert-scale.

Since all firms in the sampling frame were employing outplacement, in order to evaluate the effect of outplacement on the dependent variables, participants' satisfaction level of the outplacement applications in their firms were asked with only one question "Are you satisfied with your firm's support to the job leavers in finding a new job?" using five point Likert-scale.

Since all firms in the sampling frame were employing outplacement, in order to evaluate the effect of outplacement on the dependent variables, participants' satisfaction level of the outplacement applications in their firms were asked with only one question "Are you satisfied with your firm's support to the job leavers in finding a new job?" using five point Likert-scale.

Since all firms in the sampling frame were employing outplacement, in order to evaluate the effect of outplacement on the dependent variables, participants' satisfaction level of the outplacement applications in their firms were asked with only one question "Are you satisfied with your firm's support to the job leavers in finding a new job?" using five point Likert-scale. 
Since all firms in the sampling frame were employing outplacement, in order to evaluate the effect of outplacement on the dependent variables, participants' satisfaction level of the outplacement applications in their firms were asked with only one question "Are you satisfied with your firm's support to the job leavers in finding a new job?" using five point Likert-scale.

Participants' job satisfaction in general terms was measured with a scale consisted of 4 items (Table 3 ) (i.e. "I am often bored with my job [R]"), developed by Douglas B. Currivan (1999). Results of factor analysis (varimax rotated; $\mathrm{KMO}=, 67$ Barlett's Test $\mathrm{p}<0,01$; total variance explained $62 \%$ ) confirmed that the scale consisted of one dimension and Cronbach a value of the scale (.71) showed it was reliable.

Although recent theoretical developments in the commitment literature have higlighted the importance of employees' "multiple commitments" (Meyer and Allen, 1997; Mowday, 1998; Baruch, 1998; Johnson, 19999), the most consistent relationships found in the research have been between affective organisational commitment and various performance indicies (Metcalfe and Dick, 2001: 399-420). So in the research the affective commitment preferred as a commitment type and the Participants' affective commitment to organization was measured with a scale developed by Allen \& Meyer (1990) consisting of 6 items (i.e. "I would be very happy to spend the rest of my career with this company") (Table 4). Results of factor analysis (varimax rotated; $\mathrm{KMO}=, 74$ Barlett's Test $\mathrm{p}<0,01$; total variance explained $53 \%$ ) confirmed that the scale consisted of one dimension and Cronbach $\alpha$ value of the scale (.82) showed it was reliable.

In the study firms' competitive advantage was assessed from the employees' point of view. To this end a 7-item scale was developed asking the employee to evaluate superiority of his/her firm against its competitors in terms of 7 factors (quality, efficiency, profitability, innovativeness, costs, customer satisfaction, employee satisfaction) creating competitive advantage (Table 5). Results of factor analysis ( 
varimax rotated; $\mathrm{KMO}=, 88$ Barlett's Test $\mathrm{p}<0,01$; total variance explained $56 \%$ )

confirmed that the scale consisted of one dimension and Cronbach $\alpha$ value of the scale (.86) showed it was reliable.

In the study firms' competitive advantage was assessed from the employees' point of view. To this end a 7-item scale was developed asking the employee to evaluate superiority of his/her firm against its competitors in terms of 7 factors (quality, efficiency, profitability, innovativeness, costs, customer satisfaction, employee satisfaction) creating competitive advantage ( $\underline{\text { Table } 5}$ ). Results of factor analysis ( varimax rotated; $\mathrm{KMO}=, 88$ Barlett's Test $\mathrm{p}<0,01$; total variance explained $56 \%$ ) confirmed that the scale consisted of one dimension and Cronbach a value of the scale (.86) showed it was reliable.

\section{5. Analyses and Results}

According to the results of correlation analysis (Table 6), major philosophies in SHRM were significantly correlated $(p<, 01$ or $p<, 05)$ to by employees' perceptions of competitive advantage of the firm, affective commitment to organization and job satisfaction of the employees. Although the correlation coefficients were low, they seemed promising.

According to the results of correlation analysis (Table 6), major philosophies in SHRM were significantly correlated $(p<, 01$ or $p<, 05)$ to by employees' perceptions of competitive advantage of the firm, affective commitment to organization and job satisfaction of the employees. Although the correlation coefficients were low, they seemed promising. 
In order to test the hypotheses, regression analyses were conducted separately for all dependent variables (perceived competitive advantage, affective commitment and job satisfaction) (Table7).

In order to test the hypotheses, regression analyses were conducted separately for all dependent variables (perceived competitive advantage, affective commitment and job satisfaction) (Table7).

The regression model for competitive advantage (Table 8) showed that major philosophies in SHRM explain $25 \%$ of the variance in competitive advantage perceptions of the employees. According to the standardized beta coefficients it seemed that quality of working life had more (St.Beta $=, 37$ ) effect on employees' perceptions than learning organization (St.Beta $=, 27$ ). Thus, if the employees' satisfaction level from firms' quality of working life applications increase, their perceptions about firms' competitive advantage with regard to rivals increase. This is also true for employees' perceptions of firms' learning organization applications.

The regression model for affective commitment to organization (Table 9) showed that among the major philosophies in SHRM only quality of working life had a significant effect on affective commitment to organization (St.Beta $=, 32$ ) which means that if the employees' satisfaction level from firms' quality of working life applications increase, their affective commitment to organization increase.

The regression model for affective commitment to organization (Table 9) showed that among the major philosophies in SHRM only quality of working life had a significant effect on affective commitment to organization (St.Beta $=, 32$ ) which means that if the employees' satisfaction level from firms' quality of working life applications increase, their affective commitment to organization increase. 
On the other hand, none of the major philosophies in SHRM had an effect on employees' job satisfaction (Table 10).

On the other hand, none of the major philosophies in SHRM had an effect on employees' job satisfaction (Table 10).

On the other hand, none of the major philosophies in SHRM had an effect on employees' job satisfaction (Table 10).

In this paper, the effects of major philosophies in SHRM are examined on organizational outcomes. One of the major implication of our findings is that outplacement is not an indicator of organizational outcomes. The reason behind this finding may be the unawareness of the employees about the outplacement applications in their firms. Although the firms in our sample are known as using outplacement, they may not use this service for all positions (i.e. only for managerial positions) or may not convey sufficient information about the outplacement to their employees.

\section{CONCLUSION}

In this paper, the effects of major philosophies in SHRM are examined on organizational outcomes. One of the major implication of our findings is that outplacement is not an indicator of organizational outcomes. The reason behind this finding may be the unawareness of the employees about the outplacement applications in their firms. Although the firms in our sample are known as using outplacement, they may not use this service for all positions (i.e. only for managerial positions) or may not convey sufficient information about the outplacement to their employees. 
The other implication of our findings is that satisfaction with the quality of working life applications has an effect on employee's affective commitment to organization and firm's perceived competitive advantage. It seems that quality of working life applications cause employees to feel supported by their firms and this feeling increases their affective commitment towards their firms. By definition, the quality of working life gives workers greater opportunities to develop their jobs and their contributions to the overall organizational effectiveness. Our findings supported this by revealing the effect of quality of working life on firm's perceived competitive advantage. Being valued by their firms in terms of the quality of working life applications may have influenced employees' perceptions, and this may caused employees to perceive their firms better than their rivals in terms of competitive advantage.

The other implication of our findings is that satisfaction with the quality of working life applications has an effect on employee's affective commitment to organization and firm's perceived competitive advantage. It seems that quality of working life applications cause employees to feel supported by their firms and this feeling increases their affective commitment towards their firms. By definition, the quality of working life gives workers greater opportunities to develop their jobs and their contributions to the overall organizational effectiveness. Our 
findings supported this by revealing the effect of quality of working life on firm's perceived competitive advantage. Being valued by their firms in terms of the quality of working life applications may have influenced employees' perceptions, and this may caused employees to perceive their firms better than their rivals in terms of competitive advantage.

The other implication of our findings is that satisfaction with the quality of working life applications has an effect on employee's affective commitment to organization and firm's perceived competitive advantage. It seems that quality of working life applications cause employees to feel supported by their firms and this feeling increases their affective commitment towards their firms. By definition, the quality of working life gives workers greater opportunities to develop their jobs and their contributions to the overall organizational effectiveness. Our findings supported this by revealing the effect of quality of working life on firm's perceived competitive advantage. Being valued by their firms in terms of the quality of working life applications may have influenced employees' perceptions, and this may caused employees to perceive their firms better than their rivals in terms of competitive advantage.

The other implication of our findings is that satisfaction with the quality of working life applications has an effect on employee's affective commitment to organization and firm's perceived competitive 
advantage. It seems that quality of working life applications cause employees to feel supported by their firms and this feeling increases their affective commitment towards their firms. By definition, the quality of working life gives workers greater opportunities to develop their jobs and their contributions to the overall organizational effectiveness. Our findings supported this by revealing the effect of quality of working life on firm's perceived competitive advantage. Being valued by their firms in terms of the quality of working life applications may have influenced employees' perceptions, and this may caused employees to perceive their firms better than their rivals in terms of competitive advantage.

The other implication of our findings is that satisfaction with the quality of working life applications has an effect on employee's affective commitment to organization and firm's perceived competitive advantage. It seems that quality of working life applications cause employees to feel supported by their firms and this feeling increases their affective commitment towards their firms. By definition, the quality of working life gives workers greater opportunities to develop their jobs and their contributions to the overall organizational effectiveness. Our findings supported this by revealing the effect of quality of working life on firm's perceived competitive advantage. Being valued by their firms in terms of the quality of working life applications may have influenced 
employees' perceptions, and this may caused employees to perceive their firms better than their rivals in terms of competitive advantage.

The other implication of our findings is that satisfaction with the quality of working life applications has an effect on employee's affective commitment to organization and firm's perceived competitive advantage. It seems that quality of working life applications cause employees to feel supported by their firms and this feeling increases their affective commitment towards their firms. By definition, the quality of working life gives workers greater opportunities to develop their jobs and their contributions to the overall organizational effectiveness. Our findings supported this by revealing the effect of quality of working life on firm's perceived competitive advantage. Being valued by their firms in terms of the quality of working life applications may have influenced employees' perceptions, and this may caused employees to perceive their firms better than their rivals in terms of competitive advantage.

The other implication of our findings is that satisfaction with the quality of working life applications has an effect on employee's affective commitment to organization and firm's perceived competitive advantage. It seems that quality of working life applications cause employees to feel supported by their firms and this feeling increases their affective commitment towards their firms. By definition, the quality 
of working life gives workers greater opportunities to develop their jobs and their contributions to the overall organizational effectiveness. Our findings supported this by revealing the effect of quality of working life on firm's perceived competitive advantage. Being valued by their firms in terms of the quality of working life applications may have influenced employees' perceptions, and this may caused employees to perceive their firms better than their rivals in terms of competitive advantage.

The other implication of our findings is that satisfaction with the quality of working life applications has an effect on employee's affective commitment to organization and firm's perceived competitive advantage. It seems that quality of working life applications cause employees to feel supported by their firms and this feeling increases their affective commitment towards their firms. By definition, the quality of working life gives workers greater opportunities to develop their jobs and their contributions to the overall organizational effectiveness. Our findings supported this by revealing the effect of quality of working life on firm's perceived competitive advantage. Being valued by their firms in terms of the quality of working life applications may have influenced employees' perceptions, and this may caused employees to perceive their firms better than their rivals in terms of competitive advantage. 
The other implication of our findings is that satisfaction with the quality of working life applications has an effect on employee's affective commitment to organization and firm's perceived competitive advantage. It seems that quality of working life applications cause employees to feel supported by their firms and this feeling increases their affective commitment towards their firms. By definition, the quality of working life gives workers greater opportunities to develop their jobs and their contributions to the overall organizational effectiveness. Our findings supported this by revealing the effect of quality of working life on firm's perceived competitive advantage. Being valued by their firms in terms of the quality of working life applications may have influenced employees' perceptions, and this may caused employees to perceive their firms better than their rivals in terms of competitive advantage.

The other implication of our findings is that satisfaction with the quality of working life applications has an effect on employee's affective commitment to organization and firm's perceived competitive advantage. It seems that quality of working life applications cause employees to feel supported by their firms and this feeling increases their affective commitment towards their firms. By definition, the quality of working life gives workers greater opportunities to develop their jobs and their contributions to the overall organizational effectiveness. Our findings supported this by revealing the effect of quality of working life on firm's perceived competitive advantage. Being valued by their firms in terms of the quality of working life applications may have influenced employees' perceptions, and this may caused employees to perceive their firms better than their rivals in terms of competitive advantage. 
As a result, human resources managers and line managers in the organizations should be in cooperation for creating the quality of working life conditions. They should pay attention to better understanding the employees, determining what is important to employees, supporting their interests in and out of work, implementing worker-management participation programmes which involve giving workers the opportunity to make their decisions about their jobs, the design of their working conditions and what they need to make products or to deliver services most effectively. By the time, these efforts can provide positive contributions to the employees' productivity and the organizations' profitability.

Another implication of the findings is that being a learning organization seems to have a positive effect on employees' perceptions about their firms' competitive advantage. In other words if a firm uses more learning organization applications, its employees will perceive it better than its competitors. This may be because of providing more information and enhancing employees' awareness about the changes in the market, successes achieved by the firm and continuos developments happening in the firm. 
As a result, human resources managers and line managers in the organizations should be in cooperation for creating the quality of working life conditions. They should pay attention to better understanding the employees, determining what is important to employees, supporting their interests in and out of work, implementing worker-management participation programmes which involve giving workers the opportunity to make their decisions about their jobs, the design of their working conditions and what they need to make products or to deliver services most effectively. By the time, these efforts can provide positive contributions to the employees' productivity and the organizations' profitability.

Another implication of the findings is that being a learning organization seems to have a positive effect on employees' perceptions about their firms' competitive advantage. In other words if a firm uses more learning organization applications, its employees will perceive it better than its competitors. This may be because of providing more information and enhancing employees' awareness about the changes in the market, successes achieved by the firm and continuos developments happening in the firm. 
As a result, human resources managers and line managers in the organizations should be in cooperation for creating the quality of working life conditions. They should pay attention to better understanding the employees, determining what is important to employees, supporting their interests in and out of work, implementing worker-management participation programmes which involve giving workers the opportunity to make their decisions about their jobs, the design of their working conditions and what they need to make products or to deliver services most effectively. By the time, these efforts can provide positive contributions to the employees' productivity and the organizations' profitability.

Another implication of the findings is that being a learning organization seems to have a positive effect on employees' perceptions about their firms' competitive advantage. In other words if a firm uses more learning organization applications, its employees will perceive it better than its competitors. This may be because of providing more information and enhancing employees' awareness about the changes in the market, successes achieved by the firm and continuos developments happening in the firm. 
As a result, human resources managers and line managers in the organizations should be in cooperation for creating the quality of working life conditions. They should pay attention to better understanding the employees, determining what is important to employees, supporting their interests in and out of work, implementing worker-management participation programmes which involve giving workers the opportunity to make their decisions about their jobs, the design of their working conditions and what they need to make products or to deliver services most effectively. By the time, these efforts can provide positive contributions to the employees' productivity and the organizations' profitability.

Another implication of the findings is that being a learning organization seems to have a positive effect on employees' perceptions about their firms' competitive advantage. In other words if a firm uses more learning organization applications, its employees will perceive it better than its competitors. This may be because of providing more information and enhancing employees' awareness about the changes in the market, successes achieved by the firm and continuos developments happening in the firm. 
As a result, human resources managers and line managers in the organizations should be in cooperation for creating the quality of working life conditions. They should pay attention to better understanding the employees, determining what is important to employees, supporting their interests in and out of work, implementing worker-management participation programmes which involve giving workers the opportunity to make their decisions about their jobs, the design of their working conditions and what they need to make products or to deliver services most effectively. By the time, these efforts can provide positive contributions to the employees' productivity and the organizations' profitability.

Another implication of the findings is that being a learning organization seems to have a positive effect on employees' perceptions about their firms' competitive advantage. In other words if a firm uses more learning organization applications, its employees will perceive it better than its competitors. This may be because of providing more information and enhancing employees' awareness about the changes in the market, successes achieved by the firm and continuos developments happening in the firm.

As a result, human resources managers and line managers in the organizations should be in cooperation for creating the quality of 
working life conditions. They should pay attention to better understanding the employees, determining what is important to employees, supporting their interests in and out of work, implementing worker-management participation programmes which involve giving workers the opportunity to make their decisions about their jobs, the design of their working conditions and what they need to make products or to deliver services most effectively. By the time, these efforts can provide positive contributions to the employees' productivity and the organizations' profitability.

Another implication of the findings is that being a learning organization seems to have a positive effect on employees' perceptions about their firms' competitive advantage. In other words if a firm uses more learning organization applications, its employees will perceive it better than its competitors. This may be because of providing more information and enhancing employees' awareness about the changes in the market, successes achieved by the firm and continuos developments happening in the firm.

Final result has stated that SHRM philosophies do not have an important effect on all company management outcomes such as job satisfaction, affective commitment to organization and competitive advantage. Cultural and sectoral differences of the companies may cause to this result. For this reason, the further study can be applied in a specific sector or in the companies which are operating in different countries to find the relation between the SHRM philosophies and the company management outcomes. Further studies also can be applied in the companies which adopt and implement the SHRM philosophies and then these companies can be compared with the others which do not implement the SHRM philosophies. 
Final result has stated that SHRM philosophies do not have an important effect on all company management outcomes such as job satisfaction, affective commitment to organization and competitive advantage. Cultural and sectoral differences of the companies may cause to this result. For this reason, the further study can be applied in a specific sector or in the companies which are operating in different countries to find the relation between the SHRM philosophies and the company management outcomes. Further studies also can be applied in the companies which adopt and implement the SHRM philosophies and then these companies can be compared with the others which do not implement the SHRM philosophies.

Final result has stated that SHRM philosophies do not have an important effect on all company management outcomes such as job satisfaction, affective commitment to organization and competitive advantage. Cultural and sectoral differences of the companies may cause to this result. For this reason, the further study can be applied in a specific sector or in the companies which are operating in different countries to find the relation between the SHRM philosophies and the company management outcomes. Further studies also can be applied in the companies which adopt and implement the SHRM philosophies 
and then these companies can be compared with the others which do not implement the SHRM philosophies.

Final result has stated that SHRM philosophies do not have an important effect on all company management outcomes such as job satisfaction, affective commitment to organization and competitive advantage. Cultural and sectoral differences of the companies may cause to this result. For this reason, the further study can be applied in a specific sector or in the companies which are operating in different countries to find the relation between the SHRM philosophies and the company management outcomes. Further studies also can be applied in the companies which adopt and implement the SHRM philosophies and then these companies can be compared with the others which do not implement the SHRM philosophies.

Final result has stated that SHRM philosophies do not have an important effect on all company management outcomes such as job satisfaction, affective commitment to organization and competitive advantage. Cultural and sectoral differences of the companies may cause to this result. For this reason, the further study can be applied in a specific sector or in the companies which are operating in different countries to find the relation between the SHRM philosophies and the company management outcomes. Further studies also can be applied 
in the companies which adopt and implement the SHRM philosophies

and then these companies can be compared with the others which do

not implement the SHRM philosophies.

Final result has stated that SHRM philosophies do not have an important effect on all company management outcomes such as job satisfaction, affective commitment to organization and competitive advantage. Cultural and sectoral differences of the companies may cause to this result. For this reason, the further study can be applied in a specific sector or in the companies which are operating in different countries to find the relation between the SHRM philosophies and the company management outcomes. Further studies also can be applied in the companies which adopt and implement the SHRM philosophies and then these companies can be compared with the others which do not implement the SHRM philosophies.

\section{REFERENCES}

Biggins, David R. (April 1991), The Quality of Working Life, Social Alternatives, Vol.10, Issue.1, p.61.

Cherns, Albert (September 1975), Perspectives on the Quality of Working Life, Journal of Occupational Psychology, Vol. 48, Issue 3, p.22.

Douglas, B. Currivan (June 1999), The Causal Order of Job Satisfaction and Organizational Commitment in Models of Employee Turnover, Human Resource Management Review.

Freed, Jann E. (Jan 2001), Why Become a Learning Organization?, About Campus, Vol. 5, Issue 6, p.17.

Garcarz, Wendy and Ruth Chambers (December 2003), Creating and sustaining a learning organization in NHS, Quality in Primary Care, Vol. 11, Issue 4, p.73.

Giesecke, Joan and Beth McNeil (Summer 2004), Transitioning to the Learning Organization, Library Trends, Vol.53, Issue 1, p.65. 
Hill, Rosemary (1996), A Measure of the Learning Organization, Industrial and Training Journal, Vol.28, Issue 1, p.61.

Huang, Tung-Chun, John Lawler and Ching-Yi Lei (2007), The Effects of Quality of Work Life on Commitment An Turnover Intention, Social Behavior \& Personality: An International Journal, Vol. 35, Issue 6, p.735.

Hunter, Larry W. (1995), "How Will Competition Change Human Resources Management in Retail Banking? A Strategic Perspective", http://fic. wharton.upenn.edu/fic/papers/95/9504.pdf (Retrieved from internet 02.04.2005)

Huselid, Mark A., Susan E. Jackson and Rundell S.Schuler (February 1997), Technical and Strategic Human Resources Management Effectiveness as Determinants of Firm Performance, Academy of Management Journal, Vol.40, Issue 1, p.38.

Jauch, Lawrence R. and William F.Glueck (1988), Business Policy and Strategic Management, New York: McGraw-Hill, pp.38-71.

Jay, John (2001), Creating a Learning Organization in the Twenty-First Century, Futurics, Vol.25, Issue 1/2, p.79.

Kirk, James J. (Mar1994), Putting Outplacement in its Place, Journal of Employment Counseling, Vol. 31, Issue 1.

Knowdell, Richard L., Elizabeth Branstead and Milan Moravec (1994), From Downsizing to Recovery, California: CPP Books, p.76.

Lippitt, Gordon L. (1978), Quality Work Life; Organizational Renewal in Action, Training \& Development Journal, Vol. 32, Issue 7, p.6.

Martel, Jean-Pierre and Gilles Dupuis (2006), Quality of Work Life: Theoretical and Methodological Problems, and Presentation of a New Model and Measuring Instrument. Social Indicators Research, Vol. 77, Issue 2.

Metcalfe, Beverly and Gavin Dick (2001), Exploring organisation commitment in the police: Implications for human resource strategy, Policing: An International Journal of Police Strategies \& Management, Vol. 24, Issue: 3, pp.399-420. 
Mets, Tönis and Made Torokoff (2007), Patterns of Learning Organisation in Estonian Companies, TRAMES: A Journal of the Humanities \& Social Sciences, Vol. 11, Issue 2, p.141.

Meyer, John L. and Carolyn C. Shadle. (1994), The Changing Outplacement Process, Westport: Quorum Books, p.110-115.

Miller, Alex (1998), Strategic Management, New York: McGraw-Hill, pp.113118.

Pickman, Alan J. (1994), The Complete Guide To Outplacement Counselling, New Jersey: Lawrence Erlbaum Associates Publishers, pp.49-72.

Public Relations and Society of America, Strategic Social Responsibility http://www.prsa.org/ Networking/ssr/index.asp?int=ec1.(Retrieved from internet 03.04.2005)

Rosow, Jerome M. (April 1977), Quality of Working Life and Productivity, Work in American Institute Conference, Chicago, Illinois, p.72.

Smith, P.C.(Peggy) and Janet W. Walker (2000), Layoff Policies as a Competitive Edge, Competitiveness Review, Vol. 10 Issue 2, p.135.

Stinson, Lynn, David Pearson and Beverley Lucas (June 2006), Developing a learning culture: twelve tips for individuals, teams and organizations, Medical Teacher, Vol. 28 Issue 4.

Sweet, Donald (1991), Decruitment and Outplacement, California:AddisonWesley Publishing Company.

Tokesky, George C. and Joanne F.Kornides (1994), Strategic Human Resources is Vital, Personnel Journal, Vol.73, Issue 12, p.62.

Tompkins, Jonathan (Spring 2002), Strategic Human Resources Management in

Government : Unresolved Issues, Public Personnel Management, Vol.31, Issue 1, p.45. 
Werther, William and Keith Davis (1988), Human Resources and Personnel

Management, New York: McGraw-Hill, pp.89-110.

West, Penny (1994), The Concept of the Learning Organization, Journal of Industrial Training, Vol.18, Issue 1, pp.89-103.

Westaby, James D. (March 2004), The impact of outplacement programs on reemployment criteria: a longitudinal study of displaced managers and executives, Journal of Employment Counseling, Vol. 41, Issue 1.

Wikipedia, Strategic Management,

http://en.wikipedia.org/wiki/Strategic management

(Retrieved from internet 03.04.2005)

Wilkinson, Joyce E., Rosemary K.Rushmer and Huw T.O.Davies (March 2004), Clinical governance and the Learning Organization, Journal of Nursing Management, Vol.12, Issue 2, p.154. 